\title{
Communication
}

\section{In Vitro Coliform Resistance to Bioactive Compounds in Urinary Infection, Assessed in a Lab Catheterization Model}

\author{
Emanuel Vamanu ${ }^{1, *(\mathbb{D})}$, Laura Dorina Dinu ${ }^{1}$, Cristina Mihaela Luntraru ${ }^{2}$ and Alexandru Suciu ${ }^{2}$ \\ 1 Faculty of Biotechnology, University of Agronomic Sciences and Veterinary Medicine of Bucharest, 59 Marasti \\ Street, 011464 Bucharest, Romania; lauradorina@yahoo.com \\ 2 Hofigal Export Import SA, Intrarea Serelor No. 2, 4 District, 042124 Bucharest, Romania; \\ cristina_m_baicea@yahoo.com (C.M.L.); alexandru.suciu287@gmail.com (A.S.) \\ * Correspondence: email@emanuelvamanu.ro; Tel.: +40-742218240
}

Citation: Vamanu, E.; Dinu, L.D.;

Luntraru, C.M.; Suciu, A. In Vitro Coliform Resistance to Bioactive Compounds in Urinary Infection, Assessed in a Lab Catheterization Model. Appl. Sci. 2021, 11, 4315. https://doi.org/10.3390/app11094315

Academic Editor: Francisco Arrebola

Received: 15 April 2021

Accepted: 6 May 2021

Published: 10 May 2021

Publisher's Note: MDPI stays neutral with regard to jurisdictional claims in published maps and institutional affiliations.

Copyright: () 2021 by the authors. Licensee MDPI, Basel, Switzerland. This article is an open access article distributed under the terms and conditions of the Creative Commons Attribution (CC BY) license (https:// creativecommons.org/licenses/by/ $4.0 /)$.

\begin{abstract}
Bioactive compounds and phenolic compounds are viable alternatives to antibiotics in recurrent urinary tract infections. This study aimed to use a natural functional product, based on the bioactive compounds' composition, to inhibit the uropathogenic strains of Escherichia coli. E. coli ATCC 25922 was used to characterize the IVCM (new in vitro catheterization model). As support for reducing bacterial proliferation, the cytotoxicity against a strain of Candida albicans was also determined (over $75 \%$ at $1 \mathrm{mg} / \mathrm{mL}$ ). The results were correlated with the analysis of the distribution of biologically active compounds (trans-ferulic acid-268.44 $\pm 0.001 \mathrm{mg} / 100 \mathrm{~g}$ extract and an equal quantity of Trans-p-coumaric acid and rosmarinic acid). A pronounced inhibitory effect against the uropathogenic strain E. coli 317 (4 log copy no./mL after $72 \mathrm{~h}$ ) was determined. The results showed a targeted response to the product for tested bacterial strains. The importance of research resulted from the easy and fast characterization of the functional product with antimicrobial effect against uropathogenic strains of $E$. coli. This study demonstrated that the proposed in vitro model was a valuable tool for assessing urinary tract infections with $E$. coli.
\end{abstract}

Keywords: urinary infection; in vitro; Escherichia coli; antimicrobial

\section{Introduction}

Catheter-associated urinary tract infections (UTIs) are the most common type of nosocomial infections and are mainly significant because of the severe sequelae that affect the patient's health. E. coli is a causative agent in $80 \%$ of catheter-associated UTIs, and it has specific factors that attach to the catheter surface and then to the uroepithelium [1]. The bladder is an organ where bacterial multiplication occurs, and most symptoms result from physiological manifestations at this level. Natural control of E. coli infection is a current method based on the antimicrobial capacity of some components isolated from raw materials obtained from plants. They act by blocking microbial multiplication, reducing oxidative processes, and lowering the pressure exerted by regulating the physiological processes [2]. Functional extracts reduce biofilm formation in the urinary tract and are also an essential aspect of managing the antibiotic resistance [3].

These problems occur when, in patients with a catheter, a particular strain becomes predominant. In this situation, disturbing the microbial balance makes traditional methods inefficient. The novelties of the study in the in vitro model are the possibility of modulating simulation parameters and its adaptation to the situations in clinical practice [4]. The laboratory study provides an image of the microbiota dynamics in the urinary tract, where recurrent infections occur. New possibilities for reducing antibiotic dependence can be established and tested, which is a current trend. The modular structure allows permanent adaptation to in vivo conditions and the possibility of conducting interdisciplinary in vitro studies [5]. 
In vitro models provide a better representation of the physiological environment in the urinary tract, and they can be a valuable preclinical approach to compare and select new product formulation or to test technological innovations for the prevention of UTI. Although in vitro tests do not truly represent the complex environment in vivo, they offer many advantages, including relatively low cost, high throughput, flexibility and timeframes for testing, and no ethical concerns associated with in vivo tests [6].

Recent data indicate that herbal therapy is not inferior to antibiotic treatment in the acute phase of lower uncomplicated UTI [7,8]. This feature and the increase in interest in the use of products with low toxicity have led to the prophylactic use of extracts from plant substrates. A vital part is a combination of the antimicrobial effect with the antioxidant and anti-inflammatory effects. The correlation of these characteristics is based on the heterogeneous composition of functional extracts, which can exert several properties against E. coli infections [8]. The administration of extracts is based on the knowledge of traditional medicine. Using in vitro simulators contributes to the characterization and understanding of the intrinsic mechanisms that reduce E. coli at the urogenital level [9]. The study to assess a functional product with antibacterial properties against uropathogenic E. coli strains using the in vitro lab catheterization model. The research objectives of the study were the bioactive compounds determination by chromatographic analysis, antimicrobial effect of the product by qPCR sustained by evaluation of antimicrobial resistance and antioxidant activity. This data will provide a validation of a new in vitro catheterization model-IVCM.

\section{Materials and Methods}

\subsection{Biological Materials}

Two strains of E. coli, one ATCC 10536, from the Faculty of Biology, University of Bucharest, Romania, E. coli 317 (uropathogenic clinical isolate) and C. albicans from the Faculty of Biotechnology, University of Agronomic Sciences and Veterinary Medicine of Bucharest, Romania collection, kept at $-80{ }^{\circ} \mathrm{C}$ in glycerol, were used. The E. coli strains were revitalized by using the Lysogeny broth (LB) medium [10], and C. albicans, by using the Yeast-extract Peptone Dextrose (YPD) medium [11]. The strains were cultured in the mentioned medium at $30^{\circ} \mathrm{C}$, for $24 \mathrm{~h}$, under $120 \mathrm{rpm}$. After the incubation period, the medium was removed, and the cells were washed once with phosphate-buffered saline and resuspended in the same buffer (sterile) until they were used [12].

\subsection{Solvent Extraction}

An amount of $20 \mathrm{~g}$ of the natural product for the treatment of urinary tract infections cranberry fruit (Vaccinium vitis idaea L.), St John's-wort aerial parts (Hypericum perforatum), thyme aerial parts (Thymus vulgaris L.), propolis tincture with $27 \%$ dry mass, thyme essential oil, rosemary essential oil, and inactive ingredients) was mixed with $100 \mathrm{~mL}$ of $50 \%$ ethanol. It was stored in a Duran bottle for $48 \mathrm{~h}$ at $25{ }^{\circ} \mathrm{C}$, under $150 \mathrm{rpm}$. At the end of the period, the mixture was filtered under a vacuum and filled up to the original volume with $50 \%$ ethanol to obtain an extract in a simple tincture form. The extract was kept in brown bottles in the refrigerator and used after $48 \mathrm{~h}$ [13]. The product formula (Supplementary Figure S1) was realized to be active against urinary bladder infections both as an adjuvant in antibiotic treatment and mild forms of the infection. It can be used to prevent recurrent infections. Different biological materials were chosen because the fruit of mountain cranberry contains polyphenols and flavonoids with antiinflammatory and diuretic action, stimulating the excretion of urine procyanidins with strong antioxidant activity and bacterial antiadhesion activity [14]. Thyme powder and volatile oil have diuretic, antiseptic, and antispasmodic properties given by polyphenols, tannins, and volatile compounds [15]. Saint John's wort contains polyphenols, flavonoids and is used to alleviate inflammation, infections, and pain in urinary interstitial cystitis [16]. Propolis tincture contains polyphenols and flavonoids in high amounts, active compounds that ensure its high antioxidant activity, and contains antibacterial, anti-inflammatory, 
anesthetic, analgesic, and antibiotic properties [17]. Rosemary volatile oil has antioxidant, antiseptic, and antispasmodic properties [18].

\subsection{Determination of Extract Cytotoxicity}

Candida albicans was used as an in vivo instrument. The strain came from the Faculty of Biology, University of Bucharest, and was revitalized using the YPG environment. The protocol used the Bioscreen C MBR computer system. Different concentrations of the extract were used to determine the critical concentration, $0.062-1 \mathrm{mg} / \mathrm{mL}$. As a control, ethanol was used (solvent $50 \%$ ). The reaction mixture (YPD medium supplemented with the sample) had a maximum volume of $300 \mu \mathrm{L} /$ well, and the inoculation ratio was $10 \%$ culture $10^{8} \mathrm{CFU} / \mathrm{mL}$. The plate was introduced at $32{ }^{\circ} \mathrm{C}$ for $24 \mathrm{~h}$, with stirring and Optical Density (O.D.) was measured at $600 \mathrm{~nm}$, every $15 \mathrm{~min}$. The YPD environment was used as a positive control. The following formula was used to assess the degree of toxicity: Cytotoxicity $(\%)=\left(1-\left(\frac{O \cdot D_{\text {sample }}}{O \cdot D_{\text {control }}}\right)\right) \times 100$ [19].

\subsection{In Vitro Catheterization Model}

An in vitro model was used to evaluate the efficacy of the tested products. The steps of the method and the structure of the in vitro model were (Figure 1):

1. Duran vessel (minimum volume $1 \mathrm{~L}$ ) provided with two orifices containing sterilized artificial urine [20];

2. Peristaltic pump for regular administration of urine from the vessel of point 1 , flow rate $0.4 \mathrm{~mL} / \mathrm{min}$, controlled by a timed outlet;

3. Inoculation point with the tested strain-silicone septum (a stock culture with a minimum viability $1 \times 10^{5} \mathrm{CFU} / \mathrm{mL}$, in $0.9 \%$ sterile $\mathrm{NaCl}$ );

4. Theft made of silicone finished in a Millipore filter, diameter $0.45 \mu \mathrm{m}$;

5. In vitro bladder simulation vessel (minimum volume $250 \mathrm{~mL}$ );

6. Reaction mixture (simulated urine, the tested product, microbial strain);

7. Temperature maintenance system $-37^{\circ} \mathrm{C}$;

8. Urinary catheter;

9. Sterile sample collection vessel-Duran vessel provided with two orifices.

The heating system was based on the recirculation of water through a circuit surrounding the main simulation vessel. The model included a heating plate, a temperature sensor, a peristaltic pump that ensured a constant flow of one $\mathrm{mL} / \mathrm{min}$, and a filling vessel with a lid with three holes [21]. 


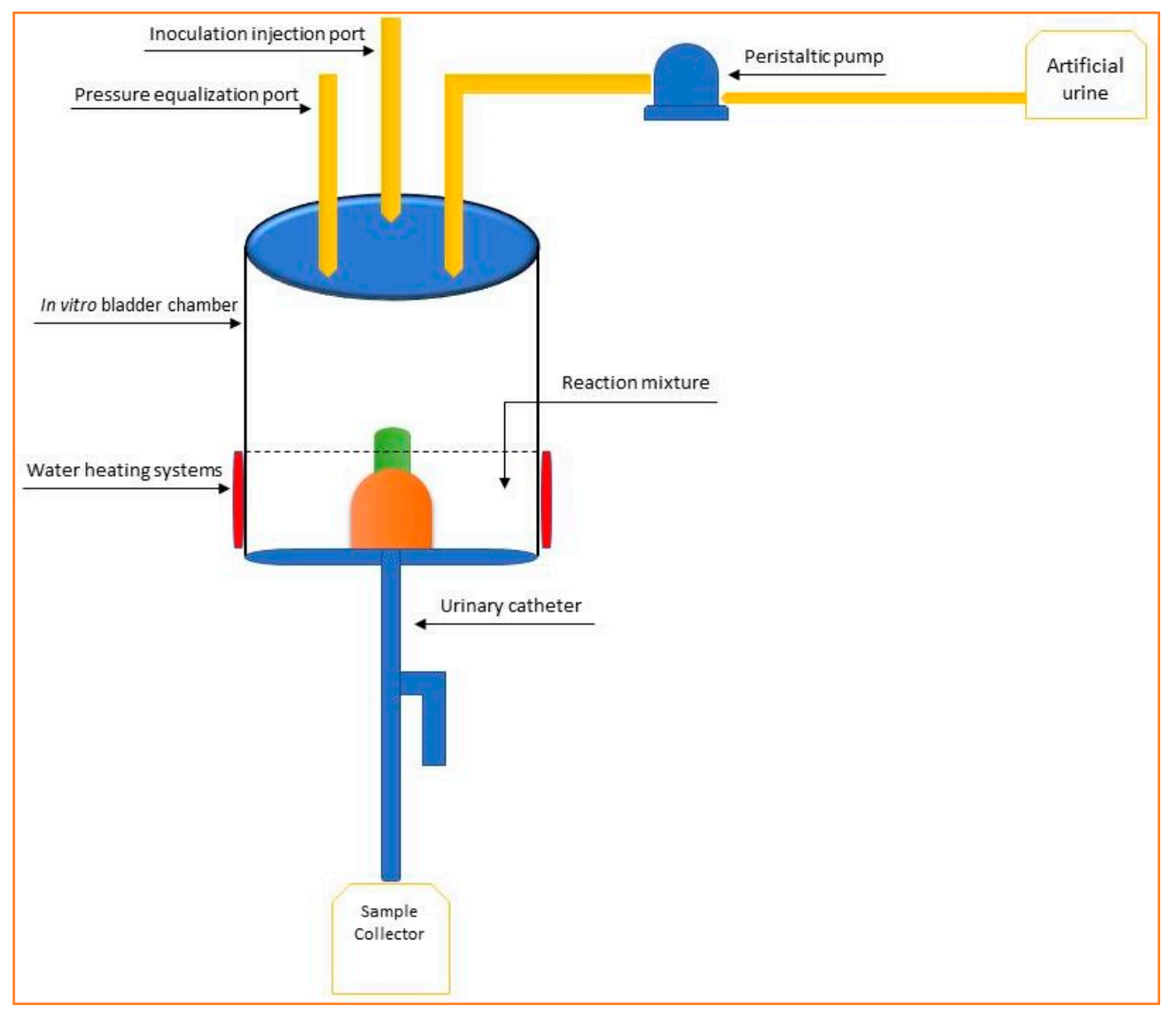

Figure 1. Schematic representation of the in vitro catheterization model.

\subsection{DNA Extraction and Quantitative Detection of E. coli Strains by qPCR}

According to the manufacturer's instructions for bacteria, genomic DNA from the bacterial cultures and samples $(1 \mathrm{~mL})$ was extracted using the Quick-DNA Miniprep Plus kit (Zymo Research, Irvine, USA). All quantitative polymerase chain reactions (qPCR) were performed using the Rotor-Gene Q (Qiagen, West Sussex, UK) instrument and software to generate the standard curve and microbial quantification. The final volume after all reactions was $20 \mu \mathrm{L}$, among them $1 \mu \mathrm{L}$ of template DNA, $4 \mu \mathrm{L}$ of $5 \times$ Hot FirePol EvaGreen qPCR Mix Plus (ROX) (Solis BioDyne, Tartu, Estonia), and $0.5 \mu \mathrm{L}$ of each universal primer: forward primer 27F (5'-AGAGTTTGATCCTGGCTCAG-3') and reverse primer 939R (5'CTTGTGCGGGCCCCCGTCAATTC- $3^{\prime}$ ) were used for the amplification of the $16 \mathrm{~S}$ rDNA gene fragment. The cycling parameters were: $12 \mathrm{~min}$ at $95^{\circ} \mathrm{C}$, followed by 40 cycles for $30 \mathrm{~s}$ at $95^{\circ} \mathrm{C}, 40 \mathrm{~s}$ at $60^{\circ} \mathrm{C}$, and $60 \mathrm{~s}$ at $72{ }^{\circ} \mathrm{C}$. Reactions were carried out in triplicate. In all cases, negative control of amplification was included using $1 \mu \mathrm{L}$ of water instead of a DNA template. A fluorescence threshold was chosen to determine the first cycle (CT) where the signals were above the threshold value. Standard curves were generated using 10-fold serial dilutions of DNA extracted from E. coli ATCC 10536 and strain 317, covering a range from $10^{-4}$ to $10^{-10}$. The coefficient of correlation (R2) obtained for the standard curve of E. coli ATCC 10536 and E. coli 317 was 0.9986 and 0.9909 , respectively, with the efficiency of the slope $\mathrm{E}=-3.32 \pm 0.11$ [22-24].

Evaluation of antibiotic susceptibility using antibiotics prescribed for treatment of recurrent urinary infections was performed by disk diffusion method on Muller-Hinton agar [25]. 


\subsection{Determination of Bioactive Compounds}

\subsubsection{Total Polyphenolic Content}

A colorimetric method was used, which was based on the Folin-Ciocalteu reagent. The calibration curve was obtained with standard solutions of gallic acid concentrations ranging from 1 to $5 \mu \mathrm{g} / \mathrm{mL}$. The reaction mixture of $1 \mathrm{~mL}$ extract, $5 \mathrm{~mL}$ Folin-Ciocalteu reagent, and $4 \mathrm{~mL}$ sodium carbonate solution was incubated for one hour. The absorbance was measured (UV-VIS spectrophotometer, Jasco V-530, Tokyo, Japan) at $765 \mathrm{~nm}$ against water [26].

\subsubsection{Procyanidins Content}

A colorimetric method was used based on the following reagents: ethanol $70 \%(v / v)$, hydrochloric acid $250 \mathrm{~g} / \mathrm{L}$ solution, and butanol. The reaction mixture was $50.0 \mathrm{~mL}$ of the obtained extract, which was evaporated in a round-bottomed flask to about $3 \mathrm{~mL}$ and transferred to a separating funnel. The round-bottomed flask was rinsed sequentially with $10 \mathrm{~mL}$ and $5 \mathrm{~mL}$ of water and transferred to a separating funnel. The combined solution was shaken with three quantities, each of $15 \mathrm{~mL}$, of butanol. The organic layers were combined and diluted to $100.0 \mathrm{~mL}$ with butanol. The solution's absorbance was measured at $555 \mathrm{~nm}$ (UV-VIS spectrophotometer, Jasco V-530, Tokyo, Japan) [27].

\subsubsection{HPLC Assay}

An aliquot of $3 \mathrm{~mL}$ of the sample was weighed and diluted with $3 \mathrm{~mL}$ of methanol. The solution was filtered through a $0.2 \mu \mathrm{m}$ polypropylene filter before high pressure liquid chromatography (HPLC) injection. Approximately $0.8 \mathrm{~g}$ of extract was ultrasonicated for $30 \mathrm{~min}$ in $20 \mathrm{~mL}$ methanol, and the solution was filtered through a $0.2 \mu \mathrm{m}$ polypropylene filter before the HPLC injection. A Hitachi Chromaster HPLC system was used, equipped with a 5160 pump, 5310 column oven, 5260 thermostated autosamplers, and a 5430 DAD detector. The separation was done on a ZORBAX SB-C18 4,6 $\times 150 \mathrm{~mm}, 3.5 \mu \mathrm{m}$ column. An adapted, reversed-phase HPLC (RP-HPLC) method was developed. The mobile phase had a mixture of acetonitrile, methanol, and water, and the elution was gradient. The analytical wavelength was set at $320,369,285$, and $267 \mathrm{~nm}$. The calibration curves were made by diluting stock solutions of each reference standard to five concentration levels. R2 values were between 0.996 and 0.999 [28].

\subsection{In Vitro Antioxidant Activity-CUPRAC (CUPric Reducing Antioxidant Capacity) Assay}

The method used a calibration curve with standard solutions of Trolox (6-hydroxy2,5,7,8-tetramethylchroman-2-carboxylic acid), with concentrations ranging from 10 to $60 \mu \mathrm{g} / \mathrm{mL}$. A $1 \mathrm{~g}$ sample was extracted with $50 \mathrm{~mL}$ of ethanol, $50 \%(v / v)$, under a reflux condenser for $30 \mathrm{~min}$. The reagents used were: Copper sulfate pentahydrate solution $10^{-2} \mathrm{M}$, neocuproine ethanolic solution $7.5 \times 10^{-3} \mathrm{M}$, ammonium acetate buffer solution $1 \mathrm{M}$, and $\mathrm{pH}$ 7. The reaction mixture contained $1 \mathrm{~mL}$ of each reagent (copper sulfate pentahydrate solution, neocuproine ethanolic solution, and ammonium acetate buffer solution), $0.1 \mathrm{~mL}$ sample, and $1.0 \mathrm{~mL}$ water and was incubated for $30 \mathrm{~min}$. The absorbance was measured (UV-VIS spectrophotometer, Jasco V-530, Tokyo, Japan) under $450 \mathrm{~nm}$, against a blank prepared with $0.1 \mathrm{~mL}$ water, instead of $0.1 \mathrm{~mL}$ sample [29].

\subsection{Statistical Analysis}

All the parameters investigated were evaluated in triplicate, with the results expressed as the mean \pm standard deviation (SD). The IBM SPSS Statistics software package (IBM Corporation, Armonk, NY, USA) was used to calculate the mean and SD values. The significance level was: significant at $p \leq 0.05$; very significant at $p \leq 0.01$; and highly significant at $p \leq 0.001$, using the normal distribution of the variables. The differences were assessed by analysis of variance (ANOVA) followed by a Tukey post-hoc analysis. The experimental data analysis and correlation were performed using the IBM SPSS Statistics software package (IBM Corporation, Armonk, NY, USA) [30,31]. 


\section{Results and Discussion}

\subsection{Determination of Bioactive Compounds}

The total polyphenol content from the natural product was $146 \mathrm{mg} / \mathrm{g}$ gallic acid equivalents. An amount of $14 \mathrm{mg} / \mathrm{g}$ pyrogallol, equivalent to tannin content, and $1.5 \mathrm{mg} / \mathrm{g}$ procyanidins, expressed as cyanidin chloride were also identified.

Chromatographic analysis of the polyfunctional extract showed a heterogeneous composition, and after the fractionation phase, the polyphenolcarboxylic acids were predominant. Trans-p-coumaric acid (203.86 $\pm 0.009 \mathrm{mg} / 100 \mathrm{~g}$ extract), rosmarinic acid (197.41 $\pm 0.006 \mathrm{mg} / 100 \mathrm{~g}$ extract), and trans-ferulic acid $(268.44 \pm 0.001 \mathrm{mg} / 100 \mathrm{~g}$ extract $)$ showed high values compared to caffeic acid (30.93 $\pm 0.004 \mathrm{mg} / 100 \mathrm{~g}$ extract).

The flavonoid composition showed the presence of rutin $(30.93 \pm 0.005 \mathrm{mg} / 100 \mathrm{~g}$ extract) and quercetin $(26.03 \pm 0.001 \mathrm{mg} / 100 \mathrm{~g}$ extract) as the major components. In addition, a much smaller amount of pinocembrin (14.67 $\pm 0.008 \mathrm{mg} / 100 \mathrm{~g}$ extract) and chrysin $(16.74 \pm 0.004 \mathrm{mg} / 100 \mathrm{~g}$ extract) were calculated.

\subsection{The Antibacterial Effect of the Extracts in the In Vitro System}

Our study tested the synergistic activity of thyme and rosemary essential oils and other ingredients used to treat urinary infections, contained in a natural product, using the in vitro catheterization model. It allowed a real-time evaluation of the microbial profile, with no infections from other strains. The product's effect on the in vitro model resulted in the inhibition of both strains, when tested after $72 \mathrm{~h}$ of simulation. The tested product (Figure 2) was shown to have a more pronounced inhibitory effect against the clinical/uropathogenic strain isolated from E. coli 317 , with viability of approximately 4 log $\mathrm{CFU} / \mathrm{mL}(p \leq 0.001)$ at $72 \mathrm{~h}$. The control strain, E. coli ATCC 10536 had superior resistance to the presence of inhibitory compounds present in the samples, $6 \log \mathrm{CFU} / \mathrm{mL}(p \leq 0.05)$ at $72 \mathrm{~h}$. These results provided an image of the role that the administration of a functional compound has on some target strains. The decrease at $72 \mathrm{~h}$ against the uropathogenic strain was at least $50 \%$ compared to the control sample.

These results provided an image of the role that the administration of a functional compound has on some target strains. The decrease at $72 \mathrm{~h}$ against the uropathogenic strain was at least $50 \%$ compared to the control sample.

Antimicrobial resistance has also been shown to be widely variable between uropathogenic E. coli clinical isolates and the standard laboratory strains [32]. Therefore, in this study we used a clinical isolate with resistance to the third-generation cephalosporin (ceftriaxone- $30 \mu \mathrm{g} / \mathrm{mL}$ and ciprofloxacin $-5 \mu \mathrm{g} / \mathrm{mL}$ ). Compared to the sensitive control, an additional explanation could be the result of the specific motility of each strain that could influence the exposure time of the strain to bioactive compounds [33].

Essential oils are complex mixtures containing up to 60 components, with 1-3 major ingredients at high concentrations. These make up a significant part of the antimicrobial activity of the essential oils. The antibacterial activity of Rosmarinus officinalis essential oil on a standard strain of E. coli ATCC 25922 and other 60 clinical strains of E coli, including the urinary tract and hospital equipment, was proved by Sienkiewicz et al. [34]. Other works compared the antibacterial activity of rosemary essential oil against different uropathogenic isolates. They noticed that the highest effect was obtained using a concentration of 10,000 ppm on E. coli, Klebsiella sp., Staphylococcus aureus, and Candida isolates [35]. Moreover, the combination of thyme and tea tree essential oils increased the guideline-recommended antibiotic activity to treat uncomplicated lower UTIs-fosfomycin and pivmecillinam, but not nitrofurantoin-against uropathogenic E. coli isolates [36]. Linalool, the major component of thyme essential oil, was shown to act as a bactericidal, fungicidal and had anti-inflammatory effects [37]. 


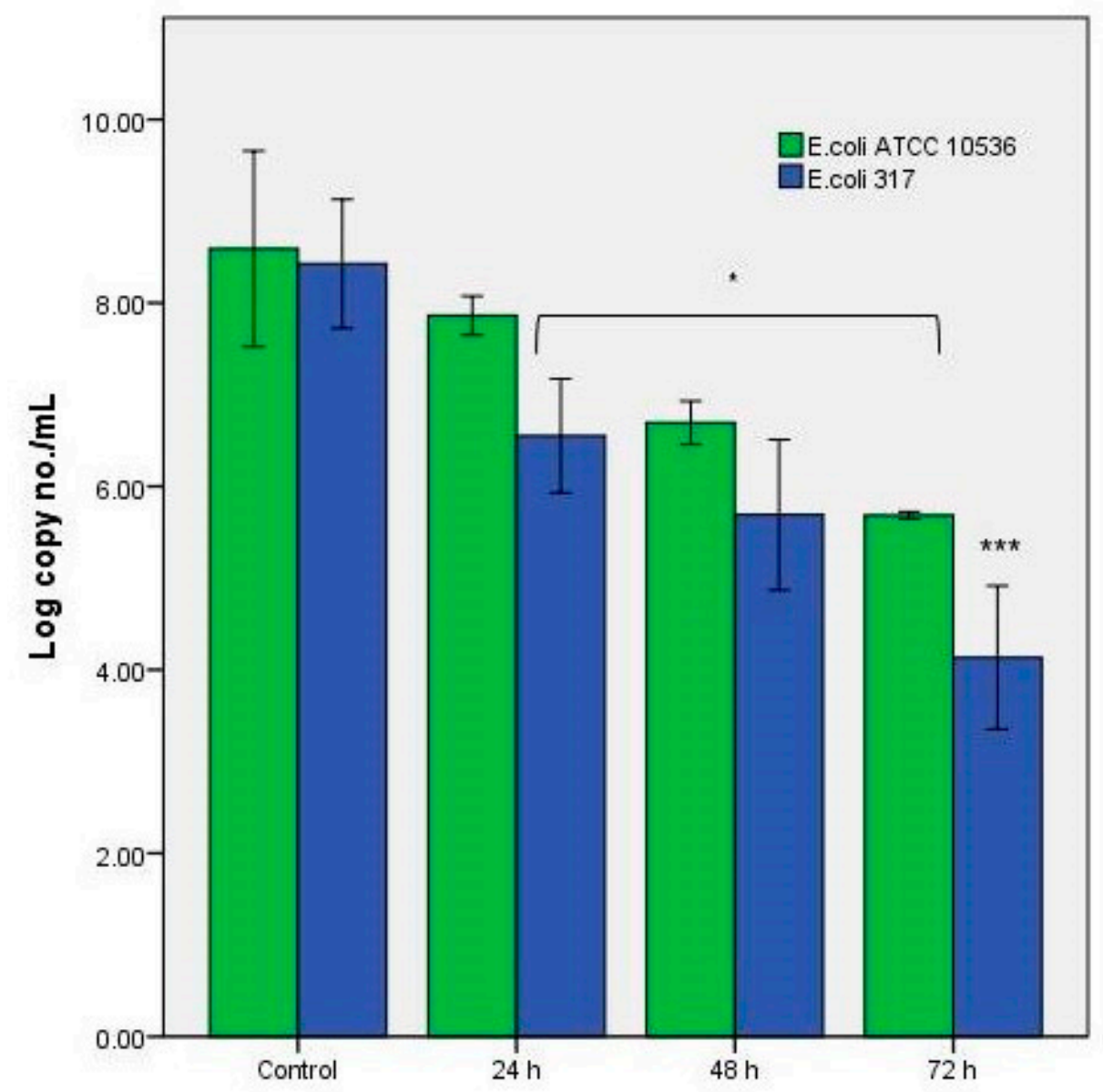

Figure 2. The antibacterial effect of the product in the in vitro catheterization system. Different asterisks represent significant statistical differences (control vs. samples; $p \leq 0.05$ ), $\mathrm{n}=3$.

It has been proved that the presence of rosmarinic acid, corresponded to the antimicrobial effect's correlation with the antioxidant one [38]. The tested product showed the antioxidant activity of $326.5 \mathrm{mg} / \mathrm{g}$ Trolox equivalent, which decreased to a quarter of its initial value at the end of the in vitro process. This result demonstrated that the bioactive load was released gradually, which gradual protection against endogenous factors. It is possible that other molecules were present în the extract (polysaccharides), influenced the bioactivity in vitro, and released the total bioactive compounds quantity [39].

\subsection{The Cytotoxicity Tests against C. Albicans}

The cytotoxicity results against $C$. albicans (Figure 3 ) demonstrated a gradual increase in the extract concentration. An average value of $47 \pm 1.63 \%(p \leq 0.01)$ was calculated for an extract of $0.062 \mathrm{mg} / \mathrm{mL}$. These results were interpreted as a functional property of the extract to modulate this strain's proliferation resistance, a relevant fact in the formation of the biofilm and the preservation of urinary tract homeostasis. The antifungal response differences were due to the variable presence of functional compounds that could be correlated with the type of bioactive molecules and biotransformations due to the environment, in vitro [40]. This feature could be considered as a limiting factor of in vitro simulators. This study demonstrated that the proposed in vitro model was a useful tool for managing UTI with E. coli. Such a laboratory model can bring the results as close as possible to those obtained in in vivo clinical trials [41]. 


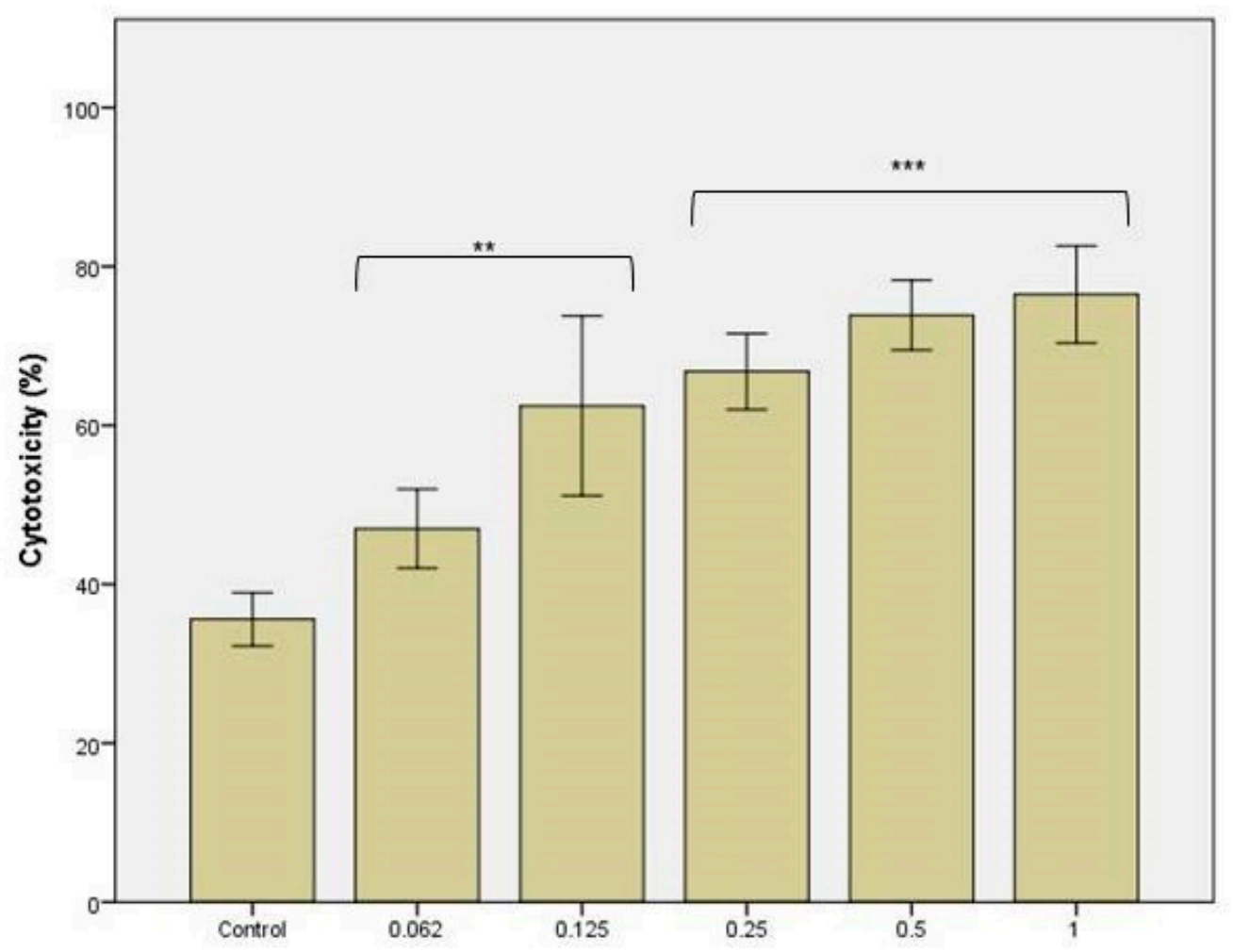

Figure 3. The cytotoxicity tests against Candida albicans. Different asterisks represent significant statistical differences (control vs. samples; $p \leq 0.05$ ), $\mathrm{n}=3$.

These results were supported by the presence of quercetin, which was reported to have urinary tract protection effects. Quercetin is used as an adjuvant to conventional treatments [42]. These data support previous studies that have shown a reduction in biofilm formation to about $65 \%$ and an inhibition in the proliferation of the Candida genus strains [43]. In addition, these compounds have prevented the formation (synthesis) of the self-produced extracellular matrix that helps build the biofilm and the recurrence of inflammatory processes. These data may have been associated with the action of other compounds, such as myricetin or catechin [44].

Another compound that expressed an antibacterial effect against $E$. coli was rosmarinic acid. Its action was synergistic in UTIs because an antioxidant effect was also determined. The expression of these effects is a specific one, with the antimicrobial effect being due to an action on the cell membrane [38,45]. The same mechanism has been demonstrated for ferulic acid [46] and in reducing the microbial biofilm [47] by decreasing the adhesion capacity of bacterial cells. The product's effectiveness was also due to the presence of coumaric acid, which is known to have similar effects in reducing bacterial cells as ferulic acid, the majority component [48]. The presence of these compounds also supported the cytotoxic effect, being correlated with the gradual decrease of the viability of the Candida strain [49].

Thus, the purpose of the study was achieved, given the inhibitory capacity of the tested extract. Static in vitro tests targeting the current model did not consider urinary epithelial interactions that may influence the bioavailability of specific compounds. This aspect can be viewed as a negative point of this type of study.

As a practical application, the realization of this model was useful for in vitro research studies that will be able to simulate certain recurrent infections. Testing the formulation of functional products and drugs with antimicrobial effects associated with inhibiting biofilm formation is another research perspective with this model in vitro. Other uropathogenic strains that can be identified with the biofilm associated with the urinary catheter can also 
be tested. New quantification and microbial analysis methods will meet practical needs regarding the presence of bacteria in the urinary tract [50].

\section{Conclusions}

This study addressed a target strain and was integrated research on the assessment of multifunctional product used in recurrent microbial infections. The study of the causes of microbial biofilm development at the urinary level will determine a clear understanding of the appearance of antibiotic resistance [51]. The in vitro model can also be adapted to other pathogenic bacterial strains and allows a complex evaluation of other functional products. Personalized analysis of the urinary microbiota response also gives the possibility of studying new therapeutic targets based on natural compounds [52].

Supplementary Materials: The following are available online at https:/ / www.mdpi.com/article/10 .3390/app11094315/s1, Figure S1: The aspect of functional product for UTIs tested in IVCM.

Author Contributions: E.V. designed the experiments, analyzed the data, and wrote the paper; A.S. and C.M.L. performed the chromatographic analysis; L.D.D. contributed with biological analyses of the samples. The authors discussed and made comments on the results. All authors have read and agreed to the published version of the manuscript.

Funding: This research received no external funding.

Institutional Review Board Statement: Not applicable.

Informed Consent Statement: Not applicable.

Data Availability Statement: Not applicable.

Conflicts of Interest: The authors declare no conflict of interest.

\section{References}

1. Flores-Mireles, A.L.; Walker, J.N.; Caparon, M.; Hultgren, S.J. Urinary tract infections: Epidemiology, mechanisms of infection and treatment options. Nat. Rev. Microbiol. 2015, 13, 269-284. [CrossRef]

2. van Seventer, J.M.; Hochberg, N.S. Principles of Infectious Diseases: Transmission, Diagnosis, Prevention, and Control. Int. Encyclop. Public Health 2017, 22-39. [CrossRef]

3. Kwiecińska-Piróg, J.; Skowron, K.; Śniegowska, A.; Przekwas, J.; Balcerek, M.; Załuski, D.; Gospodarek-Komkowska, E. The impact of ethanol extract of propolis on biofilm forming by Proteus mirabilis strains isolated from chronic wounds infections. Nat. Prod. Res. 2019, 33, 3293-3297. [CrossRef]

4. Azevedo, A.S.; Almeida, C.; Gomes, L.C.; Ferreira, C.; Mergulhão, F.J.; Melo, L.F.; Azevedo, N.F. An in vitro model of catheterassociated urinary tract infections to investigate the role of uncommon bacteria on the Escherichia coli microbial consortium. Biochem. Eng. J. 2017, 118, 64-69. [CrossRef]

5. Ceprnja, M.; Oros, D.; Melvan, E.; Svetlicic, E.; Skrlin, J.; Barisic, K.; Starcevic, L.; Zucko, J.; Starcevic, A. Modeling of Urinary Microbiota Associated With Cystitis. Front. Cell. Infect. Microbiol. 2021, 11, 643638. [CrossRef] [PubMed]

6. Cortese, Y.J.; Wagner, V.E.; Tierney, M.; Devine, D.; Fogarty, A. Review of Catheter-Associated Urinary Tract Infections and In Vitro Urinary Tract Models. J. Health. Eng. 2018, 2018, 2986742. [CrossRef]

7. Wagenlehner, F.M.; Abramov-Sommariva, D.; Höller, M.; Steindl, H.; Naber, K.G. Non-Antibiotic Herbal Therapy (BNO 1045) versus Antibiotic Therapy (Fosfomycin Trometamol) for the Treatment of Acute Lower Uncomplicated Urinary Tract Infections in Women: A Double-Blind, Parallel-Group, Randomized, Multicentre, Non-Inferiority Phase III Trial. Urol. Int. 2018, 101, 327-336. [PubMed]

8. Vamanu, E.; Pelinescu, D.; Sarbu, I. Comparative Fingerprinting of the Human Microbiota in Diabetes and Cardiovascular Disease. J. Med. Food 2016, 19, 1188-1195. [CrossRef] [PubMed]

9. Leme, D.E.M.; Rodrigues, A.B.; de Almeida-Apolonio, A.A.; Gomes da Silva Dantas, F.; Norman Negri, M.F.; Svidzinski, T.I.E.; da Silva Mota, J.; Lima Cardoso, C.A.; Pires de Oliveira, K.M. In Vitro Control of Uropathogenic Microorganisms with the Ethanolic Extract from the Leaves of Cochlospermum regium (Schrank) Pilger. Evid. Based Complement. Alt. Med. 2017, 2017, 4687154. [CrossRef] [PubMed]

10. Vamanu, E.; Pelinescu, D.; Avram, I.; Nita, S. An in vitro evaluation of antioxidant and colonic microbial profile levels following mushroom consumption. Biomed Res. Int. 2013, 2013, 289821. [CrossRef] [PubMed]

11. Forsyth, V.S.; Armbruster, C.E.; Smith, S.N.; Pirani, A.; Springman, A.C.; Walters, M.S.; Nielubowicz, G.R.; Himpsl, S.D.; Snitkin, E.S.; Mobley, H.L.T. Rapid Growth of Uropathogenic Escherichia coli during Human Urinary Tract Infection. mBIO 2018, 9 , e00186-18. [CrossRef] 
12. Chauhan, N.; Kruppa, M.D. Standard Growth Media and Common Techniques for Use with Candida albicans. In Candida albicans. Methods in Molecular Biology; Cihlar, R.L., Calderone, R.A., Eds.; Humana Press: Totowa, NJ, USA, 2009; Volume 499. [CrossRef]

13. Dabulici, C.M.; Sârbu, I.; Vamanu, E. The Bioactive Potential of Functional Products and Bioavailability of Phenolic Compounds. Foods 2020, 9, 953. [CrossRef] [PubMed]

14. Jurikova, T.; Skrovankova, S.; Mlcek, J.; Balla, S.; Snopek, L. Bioactive Compounds, Antioxidant Activity, and Biological Effects of European Cranberry (Vaccinium oxycoccos). Molecules 2018, 24, 24. [CrossRef]

15. Uritu, C.M.; Mihai, C.T.; Stanciu, G.D.; Dodi, G.; Alexa-Stratulat, T.; Luca, A.; Leon-Constantin, M.M.; Stefanescu, R.; Bild, V.; Melnic, S.; et al. Medicinal Plants of the Family Lamiaceae in Pain Therapy: A Review. Pain Res. Manag. 2018, $2018,7801543$. [CrossRef] [PubMed]

16. Olajide, O.A. Inhibitory effects of St. John's Wort on inflammation: Ignored potential of a popular herb. J. Diet. Suppl. 2009, 6, 28-32. [CrossRef] [PubMed]

17. Ahangari, Z.; Naseri, M.; Vatandoost, F. Propolis: Chemical Composition and Its Applications in Endodontics. Iran. Endod. J. 2018, 13, 285-292. [CrossRef] [PubMed]

18. Parham, S.; Kharazi, A.Z.; Bakhsheshi-Rad, H.R.; Nur, H.; Ismail, A.F.; Sharif, S.; RamaKrishna, S.; Berto, F. Antioxidant, Antimicrobial and Antiviral Properties of Herbal Materials. Antioxidants 2020, 9, 1309. [CrossRef] [PubMed]

19. Hudz, N.; Makowicz, E.; Shanaida, M.; Białoń, M.; Jasicka-Misiak, I.; Yezerska, O.; Svydenko, L.; Wieczorek, P.P. Phytochemical Evaluation of Tinctures and Essential Oil Obtained from Satureja montana Herb. Molecules 2020, 25, 4763. [CrossRef]

20. Kabir, M.A.; Hussain, M.A.; Ahmad, Z. Candida albicans: A Model Organism for Studying Fungal Pathogens. ISRN Microbiol. 2012, 2012, 538694. [CrossRef]

21. Wang, R.; Neoh, K.G.; Kang, E.T.; Tambyah, P.A.; Chiong, E. Antifouling coating with controllable and sustained silver release for long-term inhibition of infection and encrustation in urinary catheters. J. Biomed. Mater. Res. B 2015, 103, 519-528. [CrossRef]

22. Vamanu, E. In Vitro System for Testing for Urinary Tract Infection with Escherichia coli and Test Method. Patent Application OSIM 00387/2020, 8 July 2020.

23. Dinu, L.D.; Bach, S. Detection of viable but non-culturable Escherichia coli O157: H7 from vegetable samples using quantitative PCR with propidium monoazide and immunological assays. Food Control 2013, 31, 268-273. [CrossRef]

24. Rusthen, S.; Kristoffersen, A.K.; Young, A.; Galtung, H.K.; Petrovski, B.É.; Palm, O.; Enersen, M.; Jensen, J.L. Dysbiotic salivary microbiota in dry mouth and primary Sjögren's syndrome patients. PLoS ONE 2019, 14, e0218319. [CrossRef]

25. Meroni, G.; Soares Filipe, J.F.; Martino, P.A. In Vitro Antibacterial Activity of Biological-Derived Silver Nanoparticles: Preliminary Data. Vet. Sci. 2020, 7, 12. [CrossRef] [PubMed]

26. Xi, Z.Q.; Xiao, F.; Yuan, J.; Wang, X.F.; Wang, L.; Quan, F.Y.; Liu, G.W. Gene expression analysis on anterior temporal neocortex of patients with intractable epilepsy. Synapse 2009, 63, 1017-1028. [CrossRef] [PubMed]

27. Hatami, T.; Emami, S.A.; Miraghaee, S.S.; Mojarrab, M. Total Phenolic Contents and Antioxidant Activities of Different Extracts and Fractions from the Aerial Parts of Artemisia biennis Willd. Iran. J. Pharm. Res. 2014, 13, 551-559. Available online: https:/ / www.ncbi.nlm.nih.gov/pmc/articles/PMC4157030/ (accessed on 23 March 2021).

28. Cheng, A.; Chen, X.; Wang, W.; Gong, Z.; Liu, L. Contents of Extractable and Non-extractable Polyphenols in the Leaves of Blueberry. Czech J. Food Sci. 2013, 31, 275-282. Available online: https://www.agriculturejournals.cz/publicFiles/92405.pdf (accessed on 23 March 2021). [CrossRef]

29. Roman, M.C. Determination of catechins and caffeine in camillia sinensis raw materials, extracts, and dietary supplements by HPLC-uv: Single-laboratory validation. J. AOAC Int. 2013, 96, 933-941. [CrossRef]

30. Vamanu, E.; Gatea, F.; Pelinescu, D.R. Bioavailability and Bioactivities of Polyphenols Eco Extracts from Coffee Grounds after In Vitro Digestion. Foods 2020, 9, 1281. [CrossRef] [PubMed]

31. Al-Rimawi, F.; Rishmawi, S.; Ariqat, S.H.; Khalid, M.F.; Warad, I.; Salah, Z. Anticancer Activity, Antioxidant Activity, and Phenolic and Flavonoids Content of Wild Tragopogon porrifolius Plant Extracts. Evid. Based Complement. Alt. Med. 2016, 2016, 9612490. [CrossRef]

32. Ramírez-Castillo, F.Y.; Moreno-Flores, A.C.; Avelar-González, F.J.; Márquez-Díaz, F.; Harel, J.; Guerrero-Barrera, A.L. An evaluation of multidrug-resistant Escherichia coli isolates in urinary tract infections from Aguascalientes, Mexico: Cross-sectional study. Ann. Clin. Microbiol. Antimicrob. 2018, 17, 34. [CrossRef]

33. Dusane, D.H.; Hosseinidoust, Z.; Asadishad, B.; Tufenkji, N. Alkaloids Modulate Motility, Biofilm Formation and Antibiotic Susceptibility of Uropathogenic Escherichia coli. PLoS ONE 2014, 9, e112093. [CrossRef]

34. Sienkiewicz, M.; Łysakowska, M.; Pastuszka, M.; Bienias, W.; Kowalczyk, E. The potential of use basil and rosemary essential oils as effective antibacterial agents. Molecules 2013, 18, 9334-9351. [CrossRef] [PubMed]

35. Khamael, L.S.; Hassan, M.R.; Entissar, F.A. Study of rosemary essential oil antibacterial effect on bacteria isolated from urinary tract infection in some hospital of Baghdad. Curr. Res. Microb. Biotech. 2018, 6, 1490-1495. Available online: http://crmb. aizeonpublishers.net/content/2018/1/crmb1490-1495.pdf (accessed on 23 March 2021).

36. Loose, M.; Pilger, E.; Wagenlehner, F. Anti-Bacterial Effects of Essential Oils against Uropathogenic Bacteria. Antibiotics 2020, 9, 358. [CrossRef]

37. Huo, M.; Cui, X.; Xue, J.; Chi, G.; Gao, R.; Deng, X.; Guan, S.; Wei, J.; Soromou, L.W.; Feng, H. Anti-inflammatory effects of linalool in RAW 264.7 macrophages and lipopolysaccharide-induced lung injury model. J. Surg. Res. 2013, 180, e47-e54. [CrossRef] 
38. Nieto, G.; Ros, G.; Castillo, J. Antioxidant and Antimicrobial Properties of Rosemary (Rosmarinus officinalis, L.): A Review. Medicines 2018, 5, 98. [CrossRef] [PubMed]

39. Lyu, F.; Xu, X.; Zhang, L. Natural polysaccharides with different conformations: Extraction, structure and anti-tumor activity. J. Mater. Chem. B 2020, 8, 9652-9667. [CrossRef] [PubMed]

40. Lone, S.A.; Wani, M.Y.; Fru, P.; Ahmad, A. Cellular apoptosis and necrosis as therapeutic targets for novel Eugenol Tosylate Congeners against Candida albicans. Sci. Rep. 2020, 10, 1191. [CrossRef]

41. Chua, R.Y.R.; Lim, K.; Leong, S.S.J.; Tambyah, P.A.; Ho, B. An in-vitro urinary catheterization model that approximates clinical conditions for evaluation of innovations to prevent catheter-associated urinary tract infections. J. Hosp. Inf. 2017, 97, 66e73. [CrossRef]

42. Terlizzi, M.E.; Gribaudo, G.; Maffei, M.E. UroPathogenic Escherichia coli (UPEC) Infections: Virulence Factors, Bladder Responses, Antibiotic, and Non-antibiotic Antimicrobial Strategies. Front. Microbiol. 2017, 8, 1566. [CrossRef]

43. Roy, R.; Tiwari, M.; Donelli, G.; Tiwari, V. Strategies for combating bacterial biofilms: A focus on anti-biofilm agents and their mechanisms of action. Virulence 2018, 9, 522-554. [CrossRef]

44. Arita-Morioka, K.; Yamanaka, K.; Mizunoe, Y.; Tanaka, Y.; Ogura, T.; Sugimoto, S. Inhibitory effects of Myricetin derivatives on curli-dependent biofilm formation in Escherichia coli. Sci. Rep. 2018, 8, 8452. [CrossRef]

45. Nicu, I.; Pîrvu, L.; Vamanu, A. Antibacterial activity of ethanolic extracts from Agrimonia eupatoria L. and Epilobium hirsutum L. HERBA. Sci. Bull. Ser. F. Biotechnol. 2017, XXI, 127-132. Available online: http://biotechnologyjournal.usamv.ro/pdf/2017/Art2 2.pdf (accessed on 6 May 2021).

46. Borges, A.; Ferreira, C.; Saavedra, M.J.; Simões, M. Antibacterial activity and mode of action of ferulic and gallic acids against pathogenic bacteria. Microb. Drug Resist. 2013, 19, 256-265. [CrossRef] [PubMed]

47. Borges, A.; Saavedra, M.J.; Simões, M. The activity of ferulic and gallic acids in biofilm prevention and control of pathogenic bacteria. Biofouling 2012, 28, 755-767. [CrossRef] [PubMed]

48. Liu, J.; Du, C.; Beaman, H.T.; Monroe, M.B.B. Characterization of Phenolic Acid Antimicrobial and Antioxidant Structure-Property Relationships. Pharmaceutics 2020, 12, 419. [CrossRef]

49. Choi, J.H.; Park, J.K.; Kim, K.M.; Lee, H.J.; Kim, S. In vitro and in vivo antithrombotic and cytotoxicity effects of ferulic acid. J. Biochem. Mol. Toxicol. 2018, 32, 1. [CrossRef] [PubMed]

50. Nzakizwanayo, J.; Pelling, H.; Milo, S.; Jones, B.V. An In Vitro Bladder Model for Studying Catheter-Associated Urinary Tract Infection and Associated Analysis of Biofilms. Methods Mol. Biol. 2019, 2021, 139-158. [CrossRef]

51. Aslam, B.; Wang, W.; Arshad, M.I.; Khurshid, M.; Muzammil, S.; Rasool, M.H.; Nisar, M.A.; Alvi, R.F.; Aslam, M.A.; Qamar, M.U.; et al. Antibiotic resistance: A rundown of a global crisis. Infect. Drug Resist. 2018, 11, 1645-1658. [CrossRef] [PubMed]

52. Davenport, M.; Mach, K.E.; Shortliffe, L.M.D.; Banaei, N.; Wang, T.H.; Liao, J.C. New and developing diagnostic technologies for urinary tract infections. Nat. Rev. Urol. 2017, 14, 296-310. [CrossRef] 